\title{
From National Marketplaces to Global Providers of Financial Infrastructures: Exchanges, Infrastructures \& Structural Power in Global Finance ${ }^{1}$
}

\author{
Johannes Petry \\ Department of Politics and International Studies, University of Warwick \\ (j.petry@warwick.ac.uk)
}

\begin{abstract}
:
This paper analyses the role of (stock and derivative) exchanges as powerful actors in global finance. While most IPE accounts of exchanges analyse 'exchanges as marketplaces' and focus on equity market trading, they miss how exchanges have fundamentally transformed in the last 25 years. Through marketisation, internationalisation and digitisation, the business model of exchanges has fundamentally changed and led to the emergence of global exchange groups that dominate the exchange industry. Thereby, exchanges transformed from national marketplaces to global providers of financial infrastructures. They control the infrastructures that enable the functioning of capital markets: from market data, indices, financial products, trading platforms to post-trading activities such as clearing, exchanges create the rules according to which market transactions take place. This provision of financial infrastructures enables them to shape capital markets and represents a source of structural power, as exchanges potentially influence the actions of companies, investors and states entangled with these infrastructures. By shedding light on exchanges and their changed role and activities within capital markets, this paper makes a case for including exchanges as powerful actors into IPE analyses of global finance and for more closely analysing the structural power of (financial) infrastructure providers in the global economy.
\end{abstract}

Keywords: structural power, financial infrastructures, global finance, stock exchange, derivatives exchange, capital markets

\footnotetext{
${ }^{1}$ Pre-print version of the article accepted for publication in New Political Economy.
} 
We are of course known as a US exchange but that's a very small part of our business, only about 10\% of our revenue. [...] The major part of our business is what we today call FinTech. [...] So, we provide infrastructure to the world's capital markets. We have more than 100 marketplaces around the world that are using our technology for their day-today trading, clearing, settlement, risk management. [...] We sell market data in different shapes and forms from markets in Europe and the US, we do index business, licensing our indices to asset managers that provide ETF products, [...] we participate in the big derivative markets... [...] Today, we are truly a global and technology-focused company.

Senior manager, global exchange (Hong Kong, 5 July 2017).

\section{Introduction}

A development that has so far gone unnoticed in International Political Economy (IPE) is the transformation of (stock and derivative) exchanges from national marketplaces to global providers of financial market infrastructures. From market data, indices, financial products, trading platforms to post-trading activities such as clearing, exchanges shape the infrastructural arrangements of capital markets. Thereby, they enable the functioning of capital markets, but also shape their very form and dynamics, whereby they exercise structural power and potentially influence the actions of companies, investors and states. This paper analyses this transformation of exchanges from national marketplaces to powerful global actors and explores its implications for IPE analyses of global finance.

IPE scholars have extensively researched the different sources and nature of power of private actors in global finance and how this affects the relationship between states and markets (Strange 1986, 1988, Helleiner 1996, Pauly 1997). Scholars have analysed the role of credit rating agencies and technology companies as market authorities (Sinclair 2005, Campbell-Verduyn 2016), the continuous power of banks (Ertürk and Solari 2007), how hedge funds exercise power through derivatives or short-selling (Ertürk et al. 2010), or the growing power of asset managers in a shift towards passive investment (Fichtner et al. 2017). Recently, debates in IPE have focused on the infrastructural power of finance, as states become more and more entangled with financial markets (Braun 2018, Bernards and Campbell-Verduyn 2019, Genito 2019a, Gabor 2020). It is this relational entanglement with financial infrastructures that increases states' dependence on market-based finance (Braun and Gabor 2020) and provides power to financial institutions through e.g. their leveraged activities (Sgambati 2019) or involvement in repo markets (Gabor 2016).

One actor that has only received little attention in this growing body of research are exchanges. A closer look at their activities, however, highlights an important but underresearched aspect to the IPE study of financial power: Rather than studying relational entanglement with financial infrastructures, more emphasis should be put on those actors that provide financial infrastructures. Because by shaping the 'rules of the game' these infrastructure providers can exercise structural power over companies, investors and states that utilise their infrastructures. 
In the public perception, the terms 'stock exchange' and 'stock market' are often used interchangeably, mostly referring to the latter. Exchanges are depicted as marketplaces, neutral spaces where borrowers and investors meet to buy and sell ownership stakes in companies or trade commodities, derivatives or other securities. Traditionally, exchanges were merely national marketplaces, mutual non-profit organisations owned and controlled by their members, which is reflected in earlier analyses of exchanges that rather focused on those members (Baker 1984, Abolafia 1996). IPE debates have often mirrored this perception of exchanges: while they facilitate financial market transactions, exchanges themselves are not perceived and analysed as (powerful) actors, they are analysed as marketplaces or sites dominated by other actors.

Next to historical accounts of individual exchanges (e.g. Michie 1999, LagneauYmonet and Riva 2012), IPE scholars have rather focused on the impact of financial liberalisation on exchanges' members (Cerny 1989, Moran 1990), the electronification of exchanges (Zaloom 2006, Engelen and Grote 2009, Muniesa 2011, Pardo-Guerra 2019) or the politics of establishing new exchanges (Lütz 1998, Lavelle 1999, Posner 2009). Only few scholars have analysed the agency of exchanges, describing how they facilitated capital market development in other countries (Botzem and Dahl 2014), their role in the geographical constitution of stock markets (Engelen and Grote 2009, Wójcik 2012), or their instrumental power as policy actors in regulatory processes (Mügge 2006, 2011, Pagliari 2018). Others, especially scholars from the Social Studies of Finance (SSF), have researched changes in equity market trading like the advent of algorithmic/highfrequency trading (HFT) (Coombs 2016, Lange et al. 2016, Thompson 2017), the creation of non-exchange venues such as dark pools (Patterson 2012, Lagna and Lenglet 2019, MacKenzie 2019, Mattli 2019b) and the resulting fragmentation of equity markets (MacKenzie et al. 2012, Castelle et al. 2016, MacKenzie 2019, Mattli 2019a).

However, most of these accounts analyse 'exchanges as marketplaces'. ${ }^{1}$ Seddon (2019) for instance analyses the financialization of the London Metals Exchange (LME) and how competing interest groups affected LME's market structure as financial institutions gradually became more influential than merchants. Similarly, Mattli (2019a) analyses how investment banks facilitated the fragmentation of equity market trading on the New York Stock Exchange (NYSE) resulting from power asymmetries between them and other NYSE-members. Hereby, 'stock exchanges' are also equated with 'stock markets' which are defined as 'governance systems where contending groups of members or other stakeholders are frequently embroiled in intense battles to share market rules and structure' (Mattli 2019a, p. 4). To be clear, this paper does not negate any of these insightful findings. It rather argues that existing IPE literature has been preoccupied with analysing 'exchanges as marketplaces' and focusing solely on transformations in equity market trading, thereby missing how exchanges and what they do have changed fundamentally. Therefore, this paper develops a different argument about 'exchanges as (powerful) actors' in global finance.

Similar to other financial institutions, in the last 25 years exchanges and their role in capital markets have fundamentally changed. Before their transformation, exchanges were national, member-controlled, non-profit organisations and physical trading locations with a (quasi) monopoly on equity market trading, but exchanges had little 
agency of their own. However, resulting from marketisation, internationalisation and digitisation, this paper argues that the business model of exchanges has fundamentally changed. As a result, they have undergone a significant transformation from national marketplaces to global providers of financial infrastructures. As demutualised, selflisted, profit-driven and globally active technology companies, they have become (more) self-determined actors that actively create, regulate and shape (electronic) markets around the world and across asset classes, with a few global exchange groups (GEGs) dominating global markets. Rather than mere marketplaces, exchanges became complex organisations whose business was the provision of market infrastructures, whereby they shape global capital markets and their development. This paper proposes that exchanges thereby exert structural power through infrastructures and potentially influence the actions of companies, investors and states.

This paper draws on exchanges' annual corporate reports, financial news coverage, financial market databases, secondary literature and 66 semi-structured interviews conducted with exchanges, regulators and market participants in London, Frankfurt, Hong Kong, Shanghai and Singapore between May 2017 and September 2019. While quantitative data (corporate reports, databases) provides an overview of developments across exchanges, interviews enable deeper insights into these transformation processes and how exchanges exercise their power. The paper is structured as follows. Section one reviews the transformation of exchanges through marketisation, internationalisation and digitisation and how this fundamentally reconfigured the exchange industry through the emergence of GEGs and changed exchanges' business models, moving away from being national marketplaces towards becoming global providers of financial infrastructures. Section two discusses how organising and governing these infrastructures represents a source of structural power for exchanges by analysing their constitutive role in the provision of market data, indices, financial products, trading platforms and post-trade services, and how this potentially affects the actions of companies, investors and states entangled in these infrastructures. Importantly, while regulated these activities are complementary which entrenches exchanges' power against competition. Section three concludes and highlights further areas of research.

\section{Exchanges: From National Marketplaces to Global Actors}

Since the 1980s, the macro-processes of marketisation, internationalisation and digitisation have fundamentally changed exchanges and their role in capital markets. Historically, exchanges were marketplaces, physical spaces (e.g. coffee houses) where merchants met to discuss business deals and eventually agreed to jointly finance enterprises. Pre-modern forms of exchanges existed since the $14^{\text {th }}$ century in Venice, Florence and Genoa, followed by the founding of the Amsterdam Stock Exchange through the Dutch East India Company in 1602 which was the first embodiment of what is today perceived as modern stock markets (Braudel 1983, p. 101).

But from their establishment until the 1980s, exchanges did not change much. For sure, pre-modern information technologies like the telegraph changed trading practices 
and facilitated consolidation, regulation changed with recurring market crashes, existing markets matured and new markets (e.g. futures) emerged. But little about the organisational principles of what exchanges were and how they functioned changed. Historically, (almost) all exchanges were member-owned marketplaces. This 'exchange as marketplace' was a non-profit organisation and did not have much agency themselves as it was jointly governed by its members, e.g. merchants, brokers or bankers (Mattli 2019a). As Weitzman (2011, p. 184) stated, 'member control was reflected in their attitude to even the most senior exchange employees, who the traders regarded as their employees.' One interviewee made a similar point:

\footnotetext{
So, an acquaintance of mine, when he joined the [exchange] in the 1960s, one of his jobs was to dust of the partner's top hat, and the end of the day, go and sit in the first class compartment of a train, wait for the partner to come along... [...] Jack would wait for him and if he didn't get on that train, Jack would have to go sit in another train, and wait for him to arrive... that was when principals [members] owned the firms...2
}

The members ruled the exchanges, which as an organisational entity had little agency of its own. Exchanges were marketplaces that served their members through enabling the disintermediated financing of enterprises and trading of securities between investors, borrowers and lenders by said members.

Trading on the exchange took place on a trading floor, pit or ring, where only physically present members could trade a small range of products, limited both by national boundaries and/or asset classes. As NYSE's former CEO John Thain once stated 'every country has a flag, an army, and an exchange' (Biglari 2007), capturing the (unchanged) understanding of exchanges as quasi-public entities embedded in nation states and crucial for national economic development (Lütz 1998). This hardly changed over the centuries. Indeed, as a special issue in 'The Banker' (Skeete 2008) emphasised, '[u]ntil the 1980s, exchanges would, in their essentials, have been recognisable to a merchant who was trading in the 14th century - the time of their inception.' However, since the 1980s, exchanges became subject to three interlinked, mutually reinforcing processes which co-constituted their transformation and overhauled their role in capital markets.

\section{Marketisation, Internationalisation and Digitisation of Exchanges}

First, exchanges became subject to marketisation, characterised by changes in ownership and (corporate) governance structures, and the introduction of competitive dynamics. This was strongly linked to neoliberal economic reforms and restructuring; liberalisation reforms such as May Day in the US (1975), Britain's Big Bang (1986) or the EU Investment Services Directive (1993) enabled brokers to charge varying commission rates, allowed foreign participation in previously national stock markets and abolished rules requiring orders to be executed solely on exchanges, breaking down monopolies 
and barriers of entry. IPE literature on stock market liberalisation largely focused on these regulations (Cerny 1989, Moran 1990, Quaglia 2010).

However, facing such pressures, exchanges needed to modernise, become more efficient and customer-focused, while simultaneously members increasingly saw ownership as an administrative burden, a potential conflict of interest as they themselves adopted new corporate governance forms, and partially impeding their changed commercial interests (Mattli 2019a). Consequently, exchanges were demutualised, turned into for-profit companies and self-listed, becoming traded on their own markets (Aggarwal 2002). While the first member-owned exchange only demutualised in 1993, by 2013 all of the world's largest exchanges $(n=50)^{3}$ were demutualised (with the notable exception of China's state-owned exchanges). By 2018, 70\% had become publicly traded companies (see figure 3). This broke up exchanges' traditional corporate governance forms, instead of members/owners they now had shareholders and clients and, crucially, as corporate entities exchanges became more self-determined actors in their own right. As one interviewee emphasised:

I think, demutualisation is probably the most striking [change] in the fact that the exchanges are now fully in charge of their own destiny. They can decide what they want to compete on, decide what they want to launch, what areas of business they want to expand or attract from, whereas before they were looking after their own membership. [...] That has then of course allowed them to move into different areas, whether its technology, new products [...] So, I think it's really taking charge of their corporate direction... [that] is probably the biggest single change. ${ }^{4}$

While previous scholarly accounts on the workings of capital markets stress the role of members (Baker 1984, Abolafia 1996), their power to organise and responsibility to regulate the marketplace shifted towards exchanges. Through marketisation exchanges became private, marketised actors with considerable autonomy over the governance of markets but now also having to generate profits and maximise shareholder value (see, e.g. Watson 2005).

Second, from a solely national focus their business activities became increasingly international. Increasing cross-border capital market integration exposed exchanges to global markets which accelerated competitive pressures as their national markets had become too small. To expand into new markets and win new clients, from the 1990s onwards many exchanges started to internationalise their operations, opening offices around the world to gain access to local financial communities. While Chicago Mercantile Exchange (CME) was the first exchange to open an international office in 1987, in 2002 the then top-20 exchanges already had 48 offices. By 2018, the top-20 exchanges had established 212 offices (figures 1+2). 


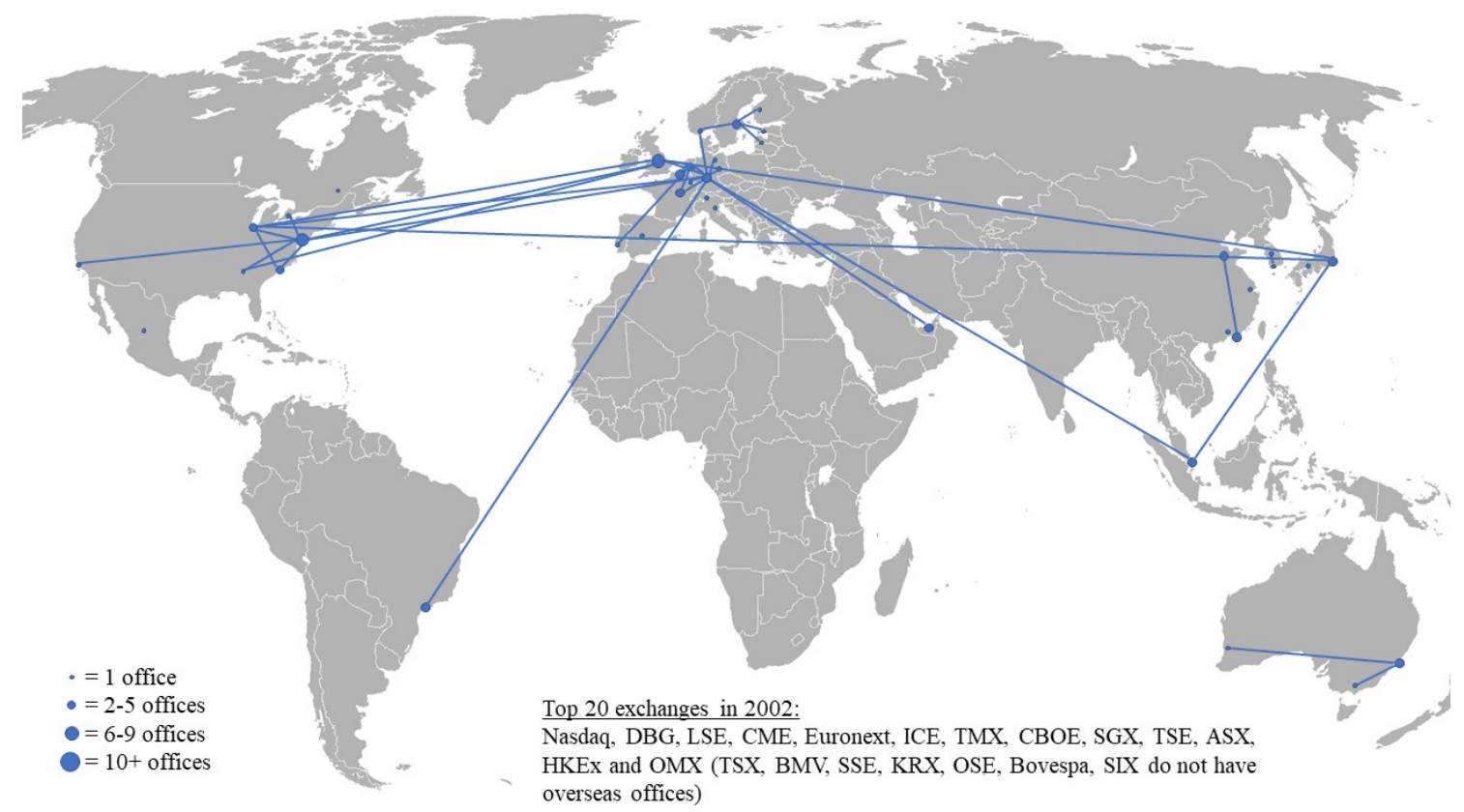

Figure 1: International offices of 20 largest exchanges in 2002 (source: annual reports, financial news).

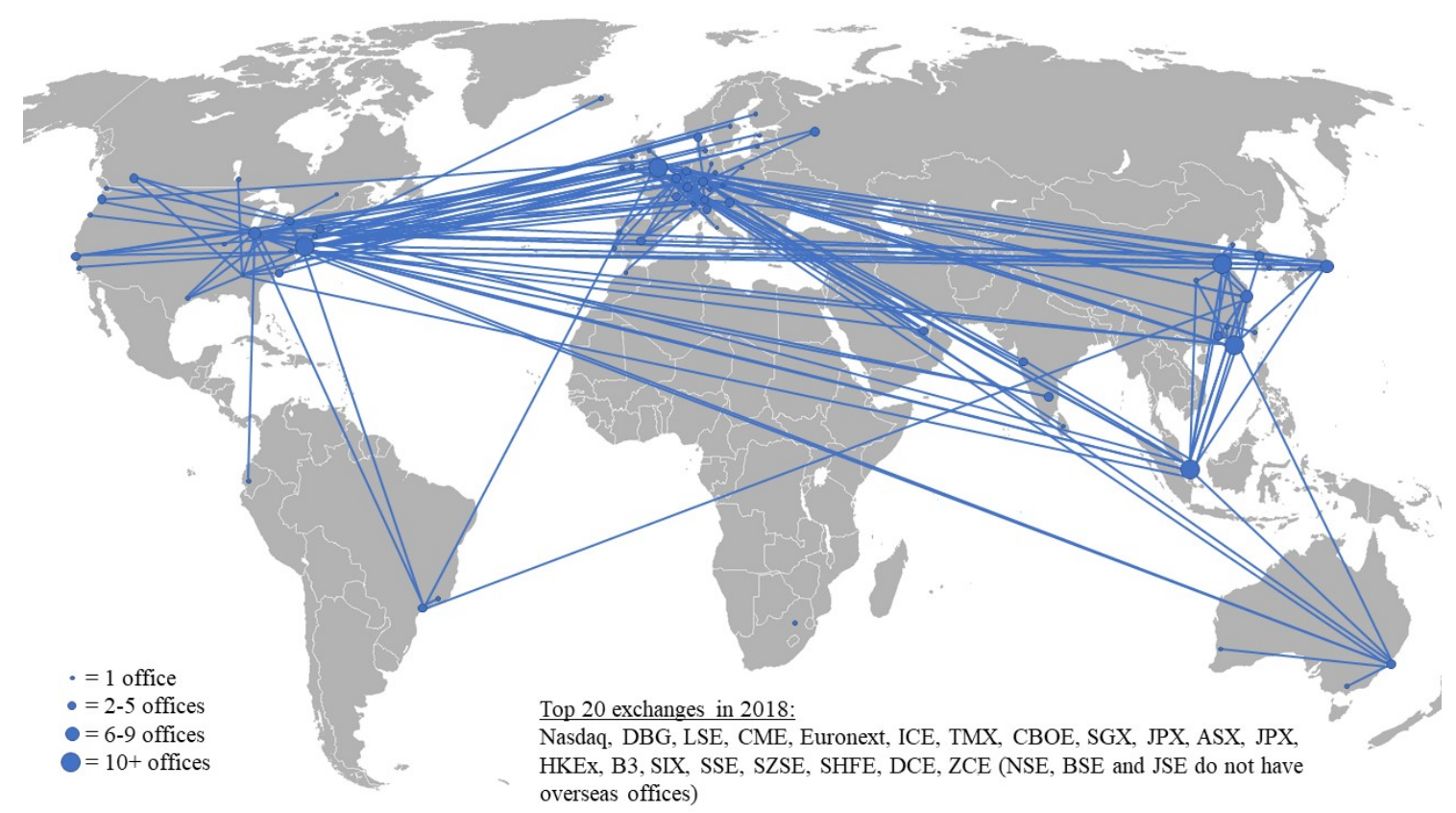

Figure 2: International offices of 20 largest exchanges in 2018 (source: annual reports, financial news).

To survive, exchanges needed to grow by engaging with and venturing into regional or global markets. In the industry, the mantra is that liquidity attracts liquidity - size matters, which facilitated mergers and acquisitions (M\&As). While first international M\&As between exchanges only occurred in the early 1990s, $68 \%$ of the largest exchanges had engaged in international M\&A activities by 2018 (see figure 3). Futures exchanges started buying stock exchanges and vice versa as well as trading venues for bonds, foreign exchange, carbon emissions, commodities or financial derivatives - with $88 \%$ of the largest exchanges offering trading in multiple asset classes in 2018 (see figure 3). 
However, as exchanges are still understood as quasi-public/national institutions with a strategic importance for their respective economies, political or regulatory reservations against further consolidation exist (Gravelle 2016), as demonstrated by several failed high-profile mergers. ${ }^{5}$ Consequently, similar to the airline industry, exchanges started to form alliances, create joint ventures, cross-list and jointly develop products or create connectivities between markets by linking their trading platforms (Domowitz 1995). From nationally focused, exchanges became globally active, a development that contemporary IPE analyses of exchanges paid little attention to (but see Botzem and Dahl 2014, Petry 2020b).

Third, exchanges changed fundamentally through technological advancements. Despite powerful images in the public mind such as commemorating IPOs, the ceremonial ringing of the bell or hectic activity on open out-cry trading floors, from the late 1990s onwards traditional face-to-face interaction had been gradually superseded by electronic trading (Gorham and Singh 2009). Instead of members physically making markets and prices in trading pits, rings and floors via open-outcry (see Zaloom 2006), exchanges replaced functions originally performed by floor-trading members by running electronic matching engine. ${ }^{6}$ Fully electronic industry newcomers like ICE, Eurex and $\mathrm{OM}$ soon acquired vast market shares across asset classes, forcing incumbent floor-based exchanges to their knees in breath-taking market showdowns (Scott and Barrett 2005). ${ }^{7}$ The future of trading was bound to become electronic. By 2013, all the world's major exchanges had adopted electronic trading, and 70\% had closed their physical trading floors by 2018 (see figure 3), often only retaining them to 'keep up appearances' - for the spectacle, news reporting and ceremonial events. Instead of requiring access to physical trading platforms in specific locations, everyone with the necessary hard- and software could participate in these markets, as long as any regulatory and organisational obstacles had been resolved. As Engelen and Grote (2009, p. 681) pointed out, exchanges were no longer the 'anchors' of financial markets.

Resulting from these processes, the traditional business of (stock) exchanges equity market trading - was rapidly changing. First, enabled by electronically and geographically connected trading venues competing for order flow, algorithmic and highfrequency trading drastically changed market activity (Lange et al. 2016, Thompson 2017). Hereby, scholars mostly focused on changing trading activities that take place on 'exchanges as marketplaces' (but see, MacKenzie 2018a, b). Second, these transformations also had wider implications for exchanges. As one interviewee noted, 'if you think about the position of exchanges, it's somewhat ironic that something that is the centre of a capitalist environment, it was really a monopoly ${ }^{8}$ However, exchanges were now in a marketplace for marketplaces (Castelle et al. 2016). Exchanges now competed with their former members/owners (e.g. banks, brokers) - who tried to side-step exchanges by setting up or backing non-exchange trading platforms, inter-dealer crossing networks or dark pools - and with one another, for listings, customers, order flow and market share (Mattli 2019b). The digitisation and liberalisation of stock markets massively drove down the price of trading, partially because newcomers had less overhead than traditional exchanges. As Mark Hemsley, CEO of BATS Europe, stated: 'We really put pressure on [the exchanges'] cost basis. [...] When we put together BATS 
and Chi-X [...] we had about 35 people on the BATS side and about 55 on the Chi-X side, so we had a total of 90 people, when we finished the integration, [...] we had the biggest stock exchange in Europe running with 50 people. ${ }^{9}$

Reforms such as Regulation ATS/NMS (1998/2005) in the US or MiFID (2005) in Europe facilitated this competition (Mügge 2011, Castelle et al. 2016) and were aimed at 'reducing the influence of [...] exchanges'(Thompson 2017, p. 7). By 2009/2010, US and European exchanges had lost $47.31 \%$ and $28.85 \%$ of stock market trading volume, respectively (Lannoo and Valiante 2010, p. 2f). This fragmentation of markets was since been analysed by several scholars (Mattli 2019a, b), especially the emergence of dark pools as non-exchange trading venues (Lagna and Lenglet 2019, MacKenzie 2019).

However, there are several shortcomings in this existing IPE literature on exchanges. First, exchanges are often only analysed as marketplaces not as actors themselves. Second, most accounts focus on changes in the traditional business of (stock) exchanges - equity market trading. Consequently, most analyses paint a picture of exchanges as incumbents fending off new competitors and/or facilitating algorithmic trading in a globalised, digitised and marketised new world, with an implicit assumption that this translates into a loss of power on behalf of exchanges. However, as this paper argues, these existing analyses are missing how exchanges and what they do have changed fundamentally.

\section{Exchanges Transformed: The New Business Model of Global Exchange Groups}

Between the 1980s and today, exchanges have morphed into fundamentally different entities. Importantly, as companies exchanges now have shareholders and customers, not members who own them (Lee 2002). As one interviewee emphasised, 'shareholders have power legally, [but] unless something has gone dreadfully wrong, they tend to be fairly inert' ${ }^{10}$ Through this changed organisational form, as corporations exchanges became more independent and self-determined (Aggarwal 2002, on corporate agency, see also Knafo and Dutta 2019). From being mere marketplaces - national, member-controlled, non-profit organisations and physical trading locations with a trading monopoly but little agency of their own - exchanges have become (more) self-determined actors demutualised, self-listed, profit-driven and globally active technology companies that operate (electronic) marketplaces around the world and across asset classes (Figure 3). 


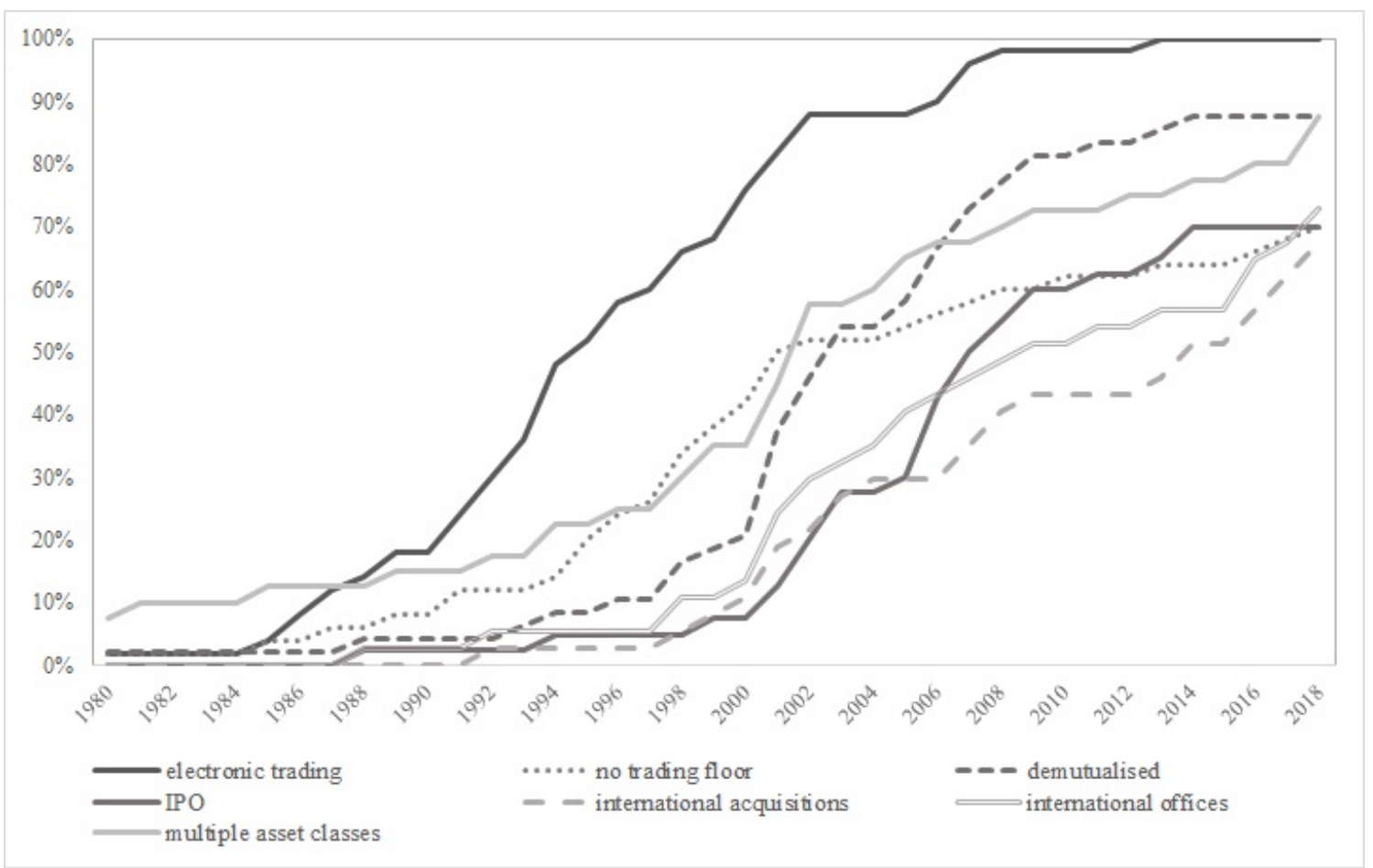

Figure 3: The transformation of exchanges, 1980-2018 (source: annual reports, exchange website information, financial news).

What exchanges are and what they do today is radically different from their previous form and function. Exchanges diversified their business horizontally - by adding new asset classes, time-zones and countries to their market portfolio - and vertically - by buying other financial service providers such as central counterparties (CCPs), index and data providers. Thereby, exchanges' business model and the structure of the exchange industry itself drastically changed.

Instead of national marketplaces, global exchange groups (GEGs) emerged that now dominate the exchange industry, a few globally active companies that run the largest, most prestigious and profitable markets, and own the most important products, indices and technological know-how (see figure 4): CME Group operates the world's largest futures market (Globex), the largest fixed income trading platform (NEX), and partially owns index provider S\&P DJI; ICE Group runs NYSE, the world's largest stock market, and several derivative exchanges such as LIFFE, NYBOT or IPE, forming the second largest derivative market globally; Nasdaq Group operates the iconic Nasdaq stock market, 28 other US and European capital markets, and its technology is used by 100+ marketplaces globally; Cboe, the world's largest options exchange, and owner of BATS, Europe's largest stock market; Deutsche Börse Group which owns index provider Stoxx, Europe's largest derivatives market (Eurex) and Clearstream, the world's largest ICSD; and LSE Group which next to the London Stock Exchange owns index provider FTSE Russell and LCH.Clearnet, the world's largest clearinghouse. 


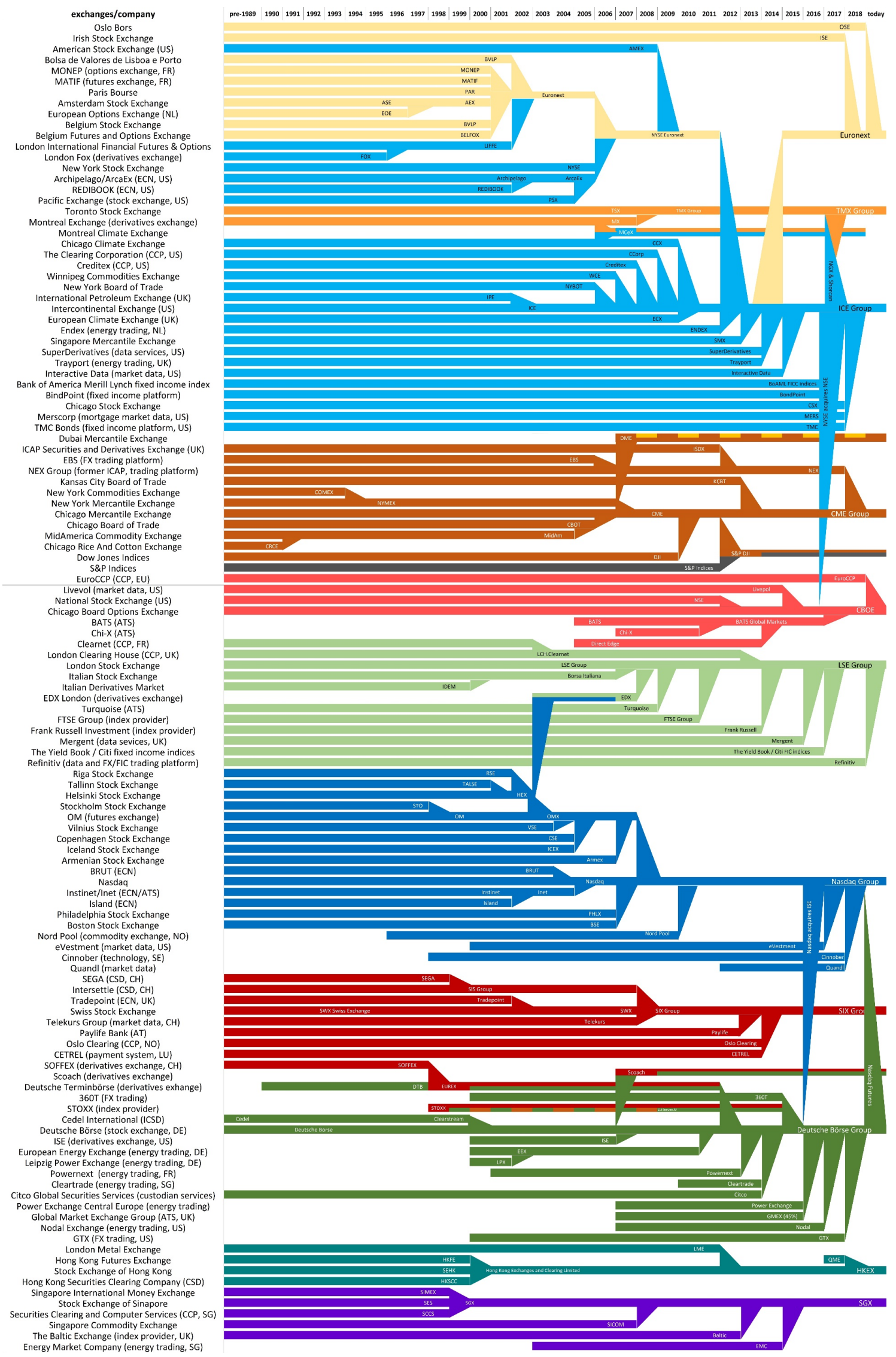

Figure 4: Consolidation in global exchange industry and emergence of global exchange groups, 1990-2018 (source: financial news coverage, annual reports). 
These five GEGs dominate the exchange industry. Complemented by a few regional players (SIX, Euronext, JSE, HKEx, SGX) and larger national exchanges (Japan, Brazil, Russia, India, China), a clear hierarchy within the exchange industry has emerged with GEGs at the top. This is also reflected in an analysis of financial industry statistics, where GEGs account for around half of equity and derivative markets trading globally, dwarfing other exchanges (see table 1).

\begin{tabular}{|c|c|c|c|c|c|c|c|c|c|}
\hline & GEGs & India & China & Brazil & Russia & Japan & $\begin{array}{l}\text { regional } \\
\text { players }\end{array}$ & other & \begin{tabular}{|ll} 
all ex- & ex \\
GEG
\end{tabular} \\
\hline $\begin{array}{l}\text { share of global exchange industry } \\
\text { revenues (\% of total) }\end{array}$ & $\sim 56 \%$ & $\mathrm{n} / \mathrm{a}$ & $\mathrm{n} / \mathrm{a}$ & $\sim 5 \%$ & $\mathrm{n} / \mathrm{a}$ & $\sim 4 \%$ & $\sim 11 \%$ & $\sim 26 \%$ & $\sim 44 \%$ \\
\hline $\begin{array}{l}\text { derivatives exchange trading } \\
\text { volume (\% of total) }\end{array}$ & $45.30 \%$ & $13.00 \%$ & $12.20 \%$ & $7.20 \%$ & $6.30 \%$ & $1.50 \%$ & $4.30 \%$ & $10.20 \%$ & $54.70 \%$ \\
\hline $\begin{array}{l}\text { derivatives exchange open } \\
\text { interest }(\% \text { of total) }\end{array}$ & $55.90 \%$ & $1.80 \%$ & $2.30 \%$ & $15.00 \%$ & $2.20 \%$ & $1.30 \%$ & $11.80 \%$ & $9.60 \%$ & $44.10 \%$ \\
\hline derivatives exchanges $(\mathrm{n}=53)$ & 6 & 3 & 4 & 1 & 1 & 4 & 5 & 30 & 47 \\
\hline $\begin{array}{l}\text { stock exchange market } \\
\text { capitalization (\% of total) }\end{array}$ & $47.50 \%$ & $5.10 \%$ & $10.30 \%$ & $1.10 \%$ & $12.40 \%$ & $0.80 \%$ & $9.00 \%$ & $13.80 \%$ & $52.50 \%$ \\
\hline $\begin{array}{l}\text { stock exchange EOB value of } \\
\text { trading ( } \% \text { of total) }\end{array}$ & $54.60 \%$ & $1.40 \%$ & $20.20 \%$ & $0.80 \%$ & $5.40 \%$ & $0.20 \%$ & $8.00 \%$ & $9.40 \%$ & $45.40 \%$ \\
\hline exchange groups $(n=83)$ & 5 & 2 & 2 & 1 & 1 & 1 & 5 & 67 & 78 \\
\hline
\end{tabular}

Table 1: Global exchange groups market share in global stock and derivative markets, 2017 (Source: FIA 2017, WFE 2017, Burton-Taylor 2018a)

In 2017, the global exchange industry made profits of USD30.7 billion, out of which GEGs accounted for $\sim 56 \%$ (Burton-Taylor 2018a). Further, EBIT margins averaged $53.6 \%$ across the industry (Burton-Taylor 2018a), outperforming most financial industries. Far from embattled incumbents struggling to survive in globalised, electronic and competitive markets, especially GEGs are thriving because their business models changed completely - they are no longer mere marketplaces for (equity) trading.

Stock trading revenues at Nasdaq for instance only contributed $11 \%$ to its revenues in 2017 while 'corporate services', 'market data' and 'technology' all became more important over time with 27.89\%, 23.72\% and 12.08\%, respectively (Nasdaq 2017). Similarly at ICE Group, albeit running the NYSE, equities only marginally contributed to its profits (13.24\%), while 'derivatives' (37.37\%) and 'data, analytics and indices' (45.02\%) generated the majority (ICE 2017). At LSE Group, stock trading revenues declined from $46.91 \%$ to $8.40 \%$ between $2007-2017$ while post-trade and index services contributed $36.72 \%$ and $37.65 \%$ in 2017 , respectively (LSE 2017). The same also applies to other exchanges: At Singapore's SGX equity trading dropped from $78.11 \%$ in 2000 to $26.17 \%$ in 2017 whereas derivatives account for $40.10 \%$ of revenues (SGX 2018). Even at Japan's relatively 'traditional' JPX Group, equity trading revenues declined from $46.55 \%$ in 1997 to $26.82 \%$ in 2017 with a simultaneous expansion of post-trade, market data and derivatives business (JPX 2017). 


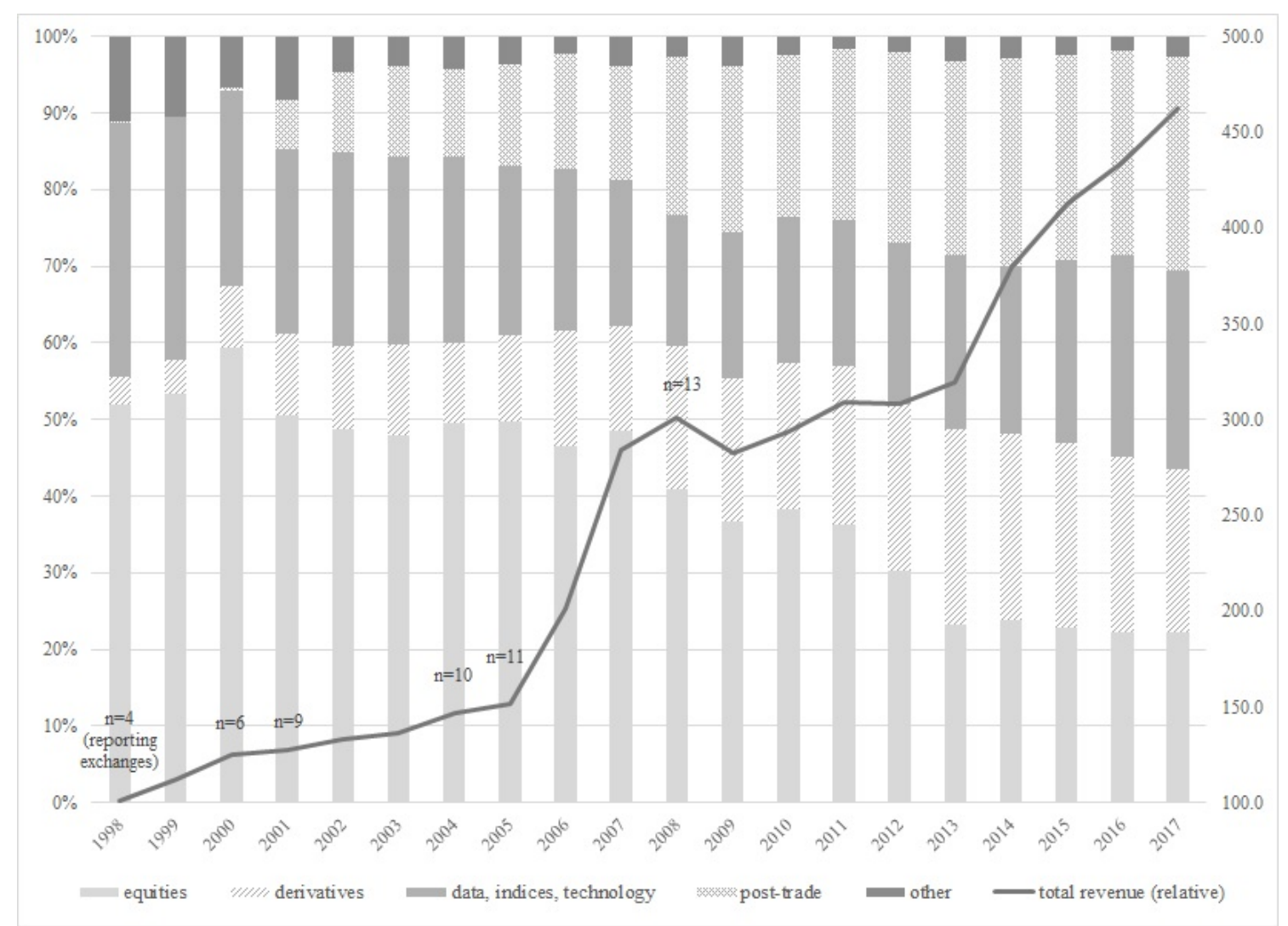

Figure 5: Revenue development of stock exchanges by business segment, 1998-2017 (source: annual reports).

A detailed analysis of revenue reporting data from exchanges' annual corporate reports $(n=214)$ of 13 stock exchanges ${ }^{11}$ between 1998-2017 (figure 5) shows that once 'traditional' stock exchanges make around $20 \%$ of their profits through the listing and trading of equities -their main source of revenue up until the end-1990s and original function for facilitating corporate finance (Zysman 1983). Instead, derivatives trading makes up 21\% of their income up from 3\% in 1998 and post-trade activities such as (derivatives) clearing and collateral management account for $28 \%$ from being virtually non-existent until 2001. Data, indices and technology remained relatively stable (25$30 \%$ ), gaining relatively in importance vis-à-vis equity trading. Simultaneously, exchanges became much larger, hugely profitable enterprises as their revenues increased five-fold. ${ }^{12}$

Exchanges have drastically changed as equity trading, their traditional business and focus of most IPE literature, has become a sideshow. Instead of single marketplaces owned by their members, exchanges have become global providers of financial market infrastructures - self-determined, global companies whose business model is vertically and horizontally integrated: horizontally, they independently organise multiple marketplaces across asset classes, countries and time-zones; vertically, they organise evermore parts of the financial value chain. This has endowed them with considerable power to shape capital markets. 


\section{Infrastructure Provision as a Source of Structural Power for Exchanges}

While financial markets are used by investors as sites of exchange, infrastructures need to be in place to enable these transaction (Bowker and Star 1999) - existing and newly emerging systems through which 'payments are settled, risks are assessed, and prices agreed' (Bernards and Campbell-Verduyn 2019, p. 777). Crucially, financial infrastructures are 'the social, cultural, and technical conditions that make [financial markets] possible' (MacKenzie 2006, p. 13), socio-technical systems that enable the functioning of markets but tend to be taken for granted and assumed (Star 1999, Edwards 2003). As Krarup (2019, p. 110) notes, 'it [infrastructure] integrates international finance'.

More than mere technical exercises, financial infrastructures are inherently political as infrastructural arrangements modify the distribution of power and capabilities within marketplaces (Riles 2011, Pardo-Guerra 2013). As Bernards and CampbellVerduyn (2019, p. 783) note, the concept of financial infrastructures 'can confer, extend and enable new forms of governance'. Drawing on Mann's (1984) work on the infrastructural power of the state, Braun (2018) for instance demonstrates how states' attempts to govern through markets provide financial actors with infrastructural power due to states' increasing entanglement with financial markets for which they rely for governance purposes (also, Braun and Gabor 2020). Infrastructure is hereby conceptualised relationally (Bernards and Campbell-Verduyn 2019), and it is this entanglement that provides financial actors with infrastructural power (Gabor 2016, Sgambati 2019), as state-market interactions take place 'on the turf and according to the rules of financial markets' (Braun and Gabor 2020, p. 241). Crucially, as Bernards and Campbell-Verduyn (2019, p. 783) emphasise, 'power often depend[s] on control over key financial infrastructures'.

This paper argues that the implications of this 'control over key financial infrastructures' (Bernards and Campbell-Verduyn 2019, p. 783) and who sets 'the rules of financial markets' (Braun and Gabor 2020, p. 241), require closer examination in the emerging IPE literature on infrastructures and power. Rather than studying relational entanglement within markets, this paper proposed to place more emphasis on those actors that provide, create and control financial market infrastructures - how and by whom markets are organised matters. Through their transformation exchanges have turned into exactly such infrastructure providers. Exchanges do not derive power through their and states' participation in financial markets, but from their role in organising the infrastructural arrangements of financial markets. Rather than instrumental or relational, their power is more architectural in nature as they shape how markets work. Instead of 'gaining under the prevailing rules of the game', through organising infrastructures exchanges can 'rewrite the rules of the game' (Cohen 1977, p. 54), and thereby constrain and influence the actions of those actors entangled within their infrastructures. Hence, the power of exchanges closely resembles what Susan Strange (1988, p. 31) defined as structural power - the ability of powerful actors 'to change the range of choices open to others without apparently putting pressure directly on them'. 


\begin{tabular}{|c|c|c|}
\hline Infrastructure & Power over whom & Effect \\
\hline \multirow{2}{*}{ data } & & monopoly power over data, pricing and access: \\
\hline & investors & profit through knowledge monopoly \\
\hline \multirow{4}{*}{ indices } & & investment-decision/standard-setting power: \\
\hline & (passive) investors & steering capital through index calculation \\
\hline & listed companies & corporate governance \\
\hline & states & investor accessibility \\
\hline \multirow{4}{*}{ products } & & defining/creating investment opportunities: \\
\hline & listed companies & more shareholder value orientation \\
\hline & investors & define range of possible investment opportunities \\
\hline & states & integration into financial circuits \\
\hline \multirow{3}{*}{ trading } & & power over trading rules: \\
\hline & investors & new incentive structures for (different) investors \\
\hline & listed companies & impatient vs. patient capital \\
\hline \multirow{3}{*}{ post-trade } & & power over investibility: \\
\hline & investors & collateral requirements influence asset allocation \\
\hline & states & potential impact on refinancing \\
\hline
\end{tabular}

Table 2: The structural power of exchanges through financial infrastructures.

Consequently, this paper argues that through providing infrastructures exchanges exert structural power over other actors. This structural power is not uniform but multifaceted as they exert their power differently over different actors through different parts of financial infrastructures (table 2). While not an exhaustive account of their activities, the following sections outline how exchanges potentially exercise this power.

\section{Market Data: Monopolies on Knowledge}

At the beginning of every trade stands an investment decision over where, when and in which products to invest. This decision is mostly based on the information available about financial products and their markets; to reduce uncertainty, calculate risks and inform investment decisions investors need market data. Especially with the rise of algorithmic trading, which now accounts between $50-70 \%$ of US and European equities trading (Mattli 2019a, p. 104), market data is crucial to 'inform' trading programs (MacKenzie 2018b, p. 1679). As SIX Group (2020) fittingly stated, 'data is the fuel of financial markets'.

The proliferation of electronic data and computing capacity opened up completely new business fields for exchanges. ${ }^{13}$ As Wójcik (2012, p. 131) noted, 'while in the mid1980s it was an achievement for SEAQ in London to execute up to 10 trades per second [...], in 2010 computers [could] generate thousands of orders per second each.' By taking on an electronic form, market data became a resource that could be utilised by exchanges who realised they sat on a gold mine. Data became something that exchanges could sell 
especially as algorithmic trading facilitated the demand for (preferential) access to realtime market data and analytics (MacKenzie et al. 2012). As one interviewee noted: 'we are of course known as a US exchange but that's a very small part of our business, [...] the major part of our business is what we today call FinTech. [...] Today we are truly a global and technology-focused company.' ${ }^{14}$

Through these data monopolies, exchanges have power over market participants. As SIFMA (2019, p. 25) noted, 'each exchange is a monopoly source of its own depthof-book data, and broker-dealers rely on that complete set of market data to achieve best execution for their customers', for which 'exchanges charge excessive fees'. As one interviewee emphasised, 'the value of an exchange [is] the price and the marketability of that price', ${ }^{15}$ as exchanges are 'the original source' of that IP-protected data. ${ }^{16}$ While companies like Bloomberg or Reuters are usually associated with financial information (Campbell-Verduyn 2016), they often license market data from exchanges. ${ }^{17}$ Exchanges have become 'content providers' (Lee 2002), selling market data, data analytics and reporting tools to their clients. This situation has recently led to debates between brokers, data vendors and exchanges about data accessibility and to repeated accusations by 'frustrated' brokers that exchanges were exercising 'monopoly pricing power'; even resulting in court cases and plans to establish a new bank-owned, US-based stock exchange, ironically called 'Members Exchange' (MEMX) (Rooney 2019).

Parallels exist hereby to big tech companies that accumulate vast quantities of knowledge from but not for market actors (Zuboff 2019, p. 17) which is ultimately linked to questions of power (Zuboff 2019, p. 176). Similarly, as Strange (1987, p. 569) pointed out when discussing US structural power, 'whoever is able to develop or acquire a kind of knowledge that is sought by others, and whoever can control the channels by which it is communicated and the access to stores of knowledge, is able to dominate'. Knowledge is power in financial markets. By deciding about market data distribution and access, exchanges are crucial in the production of knowledge about capital market activity - a position of power vis-à-vis other market participants that exchanges try to exploit for financial gains.

\section{Indices: Steering Capital through Index Calculation}

Related to market data are indices, numerical tools that enable comparative asset evaluations. The purpose of indices is to display the performance of specific (and often complex) economic entities such as national stock markets. Index providers create these indices, and they have become more powerful with the continuing shift from active towards passive investment where ETFs/index funds simply track or reproduce stock market indices (Braun 2016, Fichtner et al. 2017). Thereby, passive asset managers (e.g. BlackRock) effectively delegate their investment decision to index providers (see Petry et al. 2019). ${ }^{18}$ With the exception of MSCI, all large index providers are owned by GEGs; ${ }^{19}$ as Jan Bart de Boer, Chief Commercial Officer of ABN Amro noted: 'What is listed, traded and included in an index is decided in the realm of exchanges. ${ }^{20}$ 
Which companies or countries are in- or excluded from an index is based on criteria defined by index providers/exchanges (Rauterberg and Verstein 2013), a process that is inherently political: their notions of what constitutes good corporate governance for listed companies and a favourable investment environment for national markets helps or hinders those in attracting capital, essentially deciding what is investment-worthy in global capital markets and reinforcing compliance with their methodologies (Petry et al. 2019). As one interviewee noted: 'every exchange wants benchmarks, you can set the rules, $[\ldots]$ the benchmark owner has enormous power'. ${ }^{21}$

By rewarding compliance with capital inflows and punishing deviant behaviour with outflows, index providers are exercising structural power over both listed companies and countries, 'shaping the norms of what's considered acceptable in international finance' (Alloway et al. 2017). The recent decision by major index providers to include China and Saudi Arabia to their indices is for instance expected to result in a 'seismic shift' of over US\$120 billion in active and passive fund flows by 2020 (Robertson and Lam 2019). With the shift towards passive investment index providers have become private authorities that 'steer capital flows' and their index decisions have important effects on listed companies' corporate governance and on countries' economic policies (Petry et al. 2019).

By 2017, more than $\$ 37$ trillion active and passive assets under management tracked S\&P DJI, MSCI and FTSE Russell, who accounted for 26.6\%, 26.1\% and 25.5\% of global revenues in the index industry, respectively. Together with Stoxx (5\%) and Nasdaq (5\%), they have a market share of almost 90\% (Burton-Taylor 2018b, p. 8). As one interviewee put it: 'the big index providers, they are setting standards! Now so much money follows them, [...] they have a lot of political power! ${ }^{22}$ - or in the words of The Economist (2017), index providers 'have become finance's new kingmakers: arbiters of how investors should allocate their money.' Indices 'steer capital', providing exchanges with another lever of structural power.

\section{Financial Products: Facilitating Investment Opportunities}

The next crucial step in the financial value chain are financial products. As Leyshon and Thrift (2007, p. 98) emphasise: 'The bedrock of financial capitalism is not the spectacular system of speculation but something more mundane; that is, financial capitalism is dependent on the $[\ldots]$ construction of new asset streams, [...] which then - and only then - allows speculation to take place'. Those assets are often created, owned and/or licensed by exchanges. While 'exchanges used to have monotonous products, now they have so many', ${ }^{23}$ as one broker noted. No matter whether listed bonds, stocks, ETFs, futures or options, exchanges (help to) create, launch and attract liquidity for these products. They advertise their use, canvass investors with their sales teams and enlist market makers, playing a vital part in creating and defining what investment opportunities are - thereby indirectly shaping investor behaviour.

Exchanges for instance actively facilitate the creation of equity capital. As Wójcik (2012, p. 119) noted, the exchange 'is definitely not a passive provider of a trading system 
for equity $[\ldots]$ it takes an active role in the creation of equity, thus creating demand for its own services'. Exchanges approach unlisted companies, offer pre-IPO services that prepare them for being listed and attend, sponsor and organise conferences and trade fairs where they advertise their services. LSE Group's ELITE program for instance is a business network across 33 countries aiming to list prospective companies; as one interviewee stated, 'think of it almost like an academy, a business school for start-up companies, for young energetic companies that have a good growth potential'. ${ }^{24}$ However, by actively encouraging company listings, exchanges disseminate marketbased financial practices and associated corporate governance standards such as shareholder value orientation.

The creation of financial products is also linked to the aforementioned index business (see Petry et al. 2019) as asset managers can obtain licenses from exchanges/index providers to list ETFs on exchange-run trading platforms, and exchanges are very proactive in facilitating such product creations. ${ }^{25}$ The same holds true for derivative products, where historically exchanges have been crucial for creating new assets that enable the trading of various commodities, indices, interest rates or currencies (Millo 2007, Weitzman 2011).

As Hardie (2012, p. 15) emphasises in his study of government debt markets, by creating hedging or short-selling instruments for investors, exchanges facilitate speculative trading. Similarly, offshore index future trading influences state behaviour. In both India (Petry et al. 2019) and China (Petry 2020a) governments (feared) losing control over their domestic stock markets after SGX single-handedly listed offshorefutures based on their stock markets. As one interviewee emphasised: 'SGX are known for that... they are known for looking at an index which is successful somewhere else, create it on their trading venue to capture that volume and offer extremely obscene incentives. ${ }^{26}$ While China was forced to create index futures domestically - which the authorities were reluctant to do because they did mistrusted financial derivatives - to regain market control, ${ }^{27}$ the Indian regulator is currently working out a deal to move trading onshore. Hence, through the products that exchanges make available to investors, they integrate states into financial circuits, potentially influencing their behaviour.

By creating financial products exchanges create the necessary condition for an expansion of global finance. Thereby, they potentially influence the actions of companies seeking funding, investors seeking investment opportunities and states entangled in those markets.

\section{Trading Platforms: Shaping the Conduct of Trading}

By organising trading platforms, exchanges act as gatekeepers to markets and facilitate disintermediated processes of credit allocation, enabling investment flows between market participants. Hereby, exchanges decide according to which rules trading takes place, thereby shaping investor behaviour.

A comparison between China's state-owned exchanges and GEGs offers important insights as these facilitate very different trading infrastructures (Petry 2020a). 
In China, the government uses exchanges that facilitate state policies, for instance for finance to 'serve the real economy', to prevent 'overspeculation' or to facilitate China's 'economic reforms'. ${ }^{28}$ They do so by introducing strict position and order cancellation limits, deliberately increasing margin requirements, enforcing the physical delivery of contracts or banning investors that disregard those rules from trading - all of which influences investment decisions and market participants' behaviour.

In contrast, GEGs create incentive structures that make it profitable for investors to engage in short-term speculation rather than long-term investment, as their primary motivation is increasing trading volumes to maximise their own profits. Instead of mandatory physical delivery and position limits in China that aim to facilitate hedging, they rather discourage or simply do not enable physical delivery as cash-settled trades are more lucrative. ${ }^{29}$ GEGs also deliberately created new order types such as flash orders and offer direct market access or co-location that facilitate HFT (MacKenzie et al. 2012, Lewis 2014, Castelle et al. 2016). But if market infrastructures enable (or even encourage) speculative trading, speculating actors (e.g. hedge funds) are more likely to dominate the market. As Garratt and Hamilton (2016, p. 805) highlight 'intermediation, regulation and poor institutional incentives' crowd out long-term investors and facilitate a move towards impatient capital, influencing listed companies' corporate governance decisions.

While exchanges have undoubtfully been losing ground to trading venues such as dark pools, they still prevail in providing trading platforms: 50\% (Europe), 67\% (US) and $88 \%$ (Asia) of equity trading are still conducted on exchanges, mostly concentrated in GEGs (Reid and Jessop 2017). ${ }^{30}$ As one interviewee noted: 'if markets become volatile, liquidity in smaller marketplaces often vanishes' and there is a run to safety, 'back to the established exchanges'. ${ }^{31}$ Similarly, another interviewee emphasised 'price formation happens on the primary exchange, that's pretty fundamental...' therefore, 'you want [such] quality liquidity' ${ }^{32}$ Hence, exchanges play an active role in deciding which kind of trading they want and encourage on their platforms (MacKenzie 2018a, pp. 516-518).

By deciding on issues such as market access, contract specifications and trading rules, exchanges have an important impact on how markets function. Thereby, they exercise structural power - shaping the behaviour of investors and influencing market dynamics.

\section{Post-Trade Services: Central Clearing and Collateral}

Once investors agree on a trade, post-trade infrastructures need to be in place to execute it -most importantly by clearing transactions through CCPs. ${ }^{33}$ Especially with post-crisis regulation, such as higher capital requirements (Basel III), the push towards centrallyclearing OTC derivatives (EMIR /Dodd-Frank) or increased margin requirements for uncleared derivatives (IOSCO-BCBS), uncleared OTC derivative trading has become incredibly margin- and capital-intensive. As one interviewee noted:

In 2010 people started saying, what are your margin levels? In my previous 20 years of working in finance, no one ever asked that question... Now it is important for the banks 
and even more so with the new regulations, cost of capital and everything else, their margin is everything! ${ }^{34}$

Consequently, by Q3-2019 clearing of interest rate and credit derivatives (accounting for $\sim 80 \%$ of OTC derivatives) rose to $90.0 \%$ and $81.4 \%$ of notional trading volume, respectively (ISDA 2019). Central clearing has become a key feature of today's derivatives markets (Helleiner et al. 2018, Genito 2019a).

However, there has been a significant change in CCP ownership in recent years as exchanges acquired evermore CCPs in their push to becoming infrastructure providers. In 2014, exchanges owned 83\% of CCPs globally up from 55\% in 2006 (Domanski et al. 2015), a figure that has since increased with CBOE's and LSE's (partial) acquisitions of EuroCCP and LCH.Clearnet. Further, clearing is highly concentrated. By 2014, 99\% and $59 \%$ of global OTC and exchange-traded derivative clearing was conducted by five CCPs (Wendt 2015, p. 13) and the top-10 CCPs accounted for $88 \%$ of all CCPs' financial resources globally (FSB et al. 2017, p. 2), all of which are owned by exchanges (Khwaja 2019). ${ }^{35}$ New interdependencies that have already raised regulatory concerns (FSB et al. 2017).

This provides exchanges with another facet of structural power through infrastructure. CCPs have unilateral decision-making power on collateral and capital requirements when clearing financial transactions, basically deciding which assets they deem safe enough to back transactions. Thereby, CCPs can constrain how investors can allocate liquid assets (Genito 2019a, p. 939). With higher mandatory margin requirements, for instance, investor demand for collateral lending has increased, and CCPs started engaging in 'collateral transformation', i.e. lending collateral to investors from their own margin pool, thereby enabling continued trading. ${ }^{36}$ As one interviewee noted, 'what it actually does, is reducing your capital requirement quite significantly' ${ }^{37}$ whereby CCPs partially help banks to circumvent post-crisis regulations. ${ }^{38}$

By shaping financial institutions' balance sheets, CCPs thereby have considerable influence not only within capital markets but also on the actions of states. This could for instance be observed in the European sovereign debt crisis as LCH.Clearnet's margin calls on sovereign bonds used as collateral significantly increased the risk premium on governments' ability to refinance their debt (Genito 2019b).

CCPs have the ability to influence both investors' asset allocation as well as states and their policy decisions. Through CCP-ownership, exchanges can exercise structural power through another infrastructural arrangement of capital markets. 


\section{Power within Limits: Complementarity, Competition and Regulation}

Of course, exchanges might be challenged in individual aspects of their business model, e.g. dark pools in the case of trading platforms. But it's their ownership of infrastructures along the whole financial value chain that locks in their competitive advantage (Figures $6,7) .{ }^{39}$ As one interviewee stated:

Because we own so much more of the value chain, $[\ldots]$ we have revenues stream out of every aspect of that. [...] You really want something that has synergistic... complementarity... [...] Next to the stock market, we have the no.1 platform for launching and trading ETFs. Then we have the futures business, which is used for hedging those ETFs, and then off course, I mentioned all the data that flows alongside in that silo. [...] That's basically how we try to shape the business, as an entire value chain where clients want to see that all on a single platform where they can have a single trading access or, more importantly, a single clearing access... So, they can do cross margining, long-short trades, cross-spreads, etc.... they want to have that all in one place because it's much more capital efficient. ${ }^{40}$

\section{Deutsche Börse Group Services}

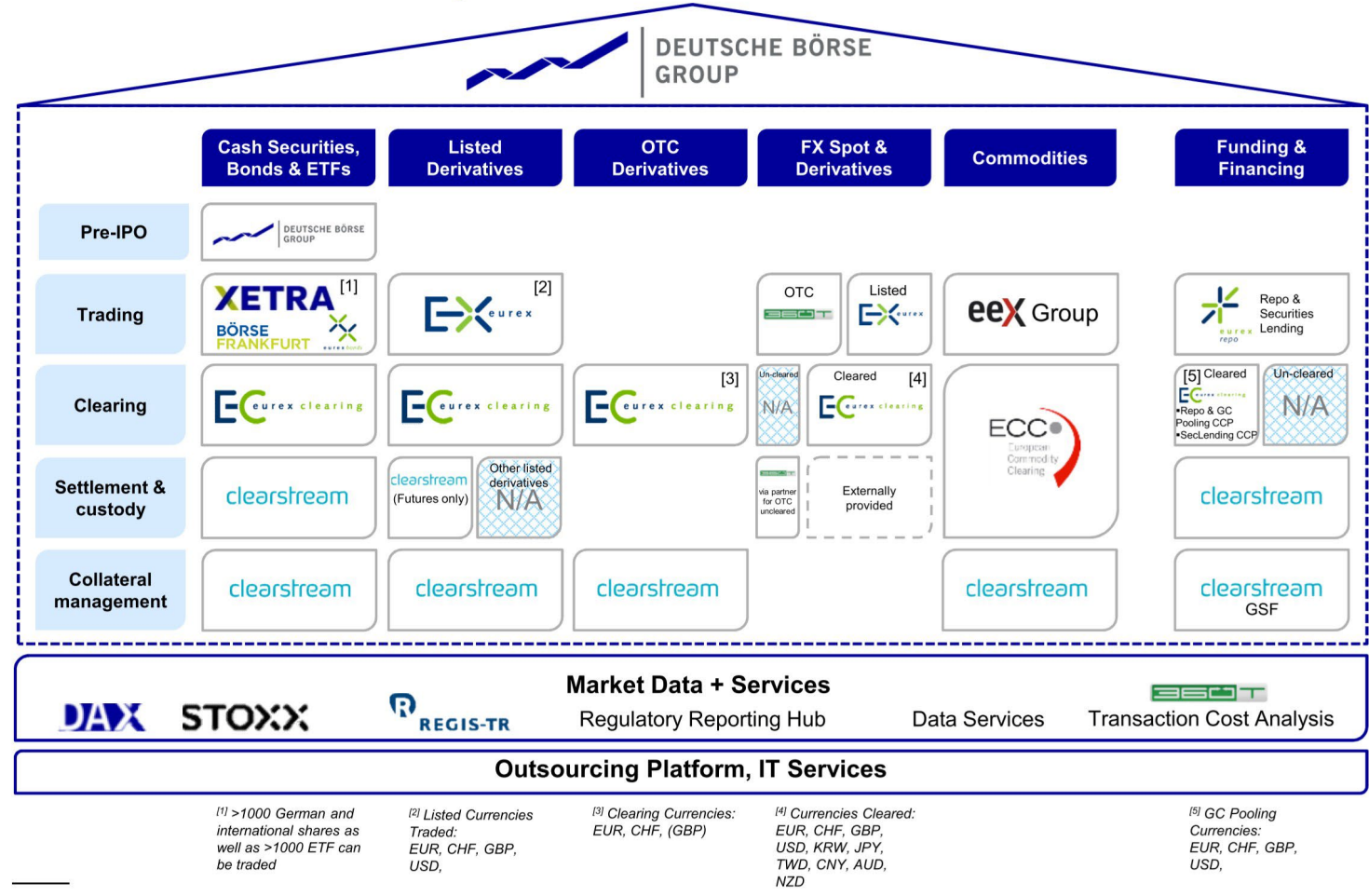

Figure 6: Deutsche Börse Group business model as integrated infrastructure provider, August 2017 (source: investor presentation). 


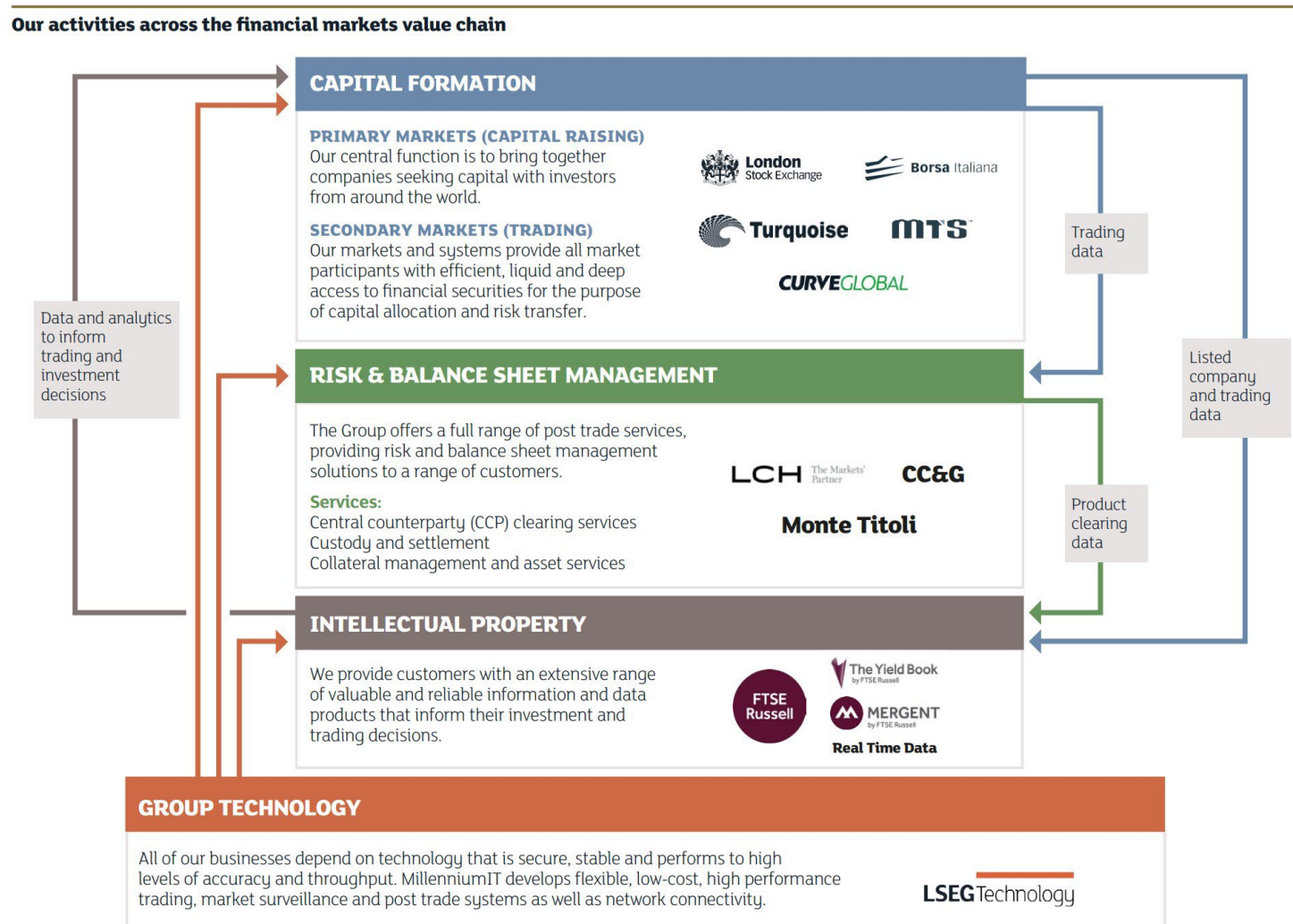

Figure 7: LSE Group business model as integrated infrastructure provider, December 2017 (source: LSE (2017).

These 'network effects' are very difficult to achieve for newcomers. Similarly, another interviewee noted: 'I mean if you have a listing, then you have an index, you have the trading, you have the clearing, then you have the settlement. It makes it very difficult for a company to move away from that, so it's a very sticky business model'. ${ }^{41}$ GEGs therefore market themselves as one-stop-solutions where customers are strongly encouraged to use all their services. In addition, their business is scalable, because 'I have exactly the same overhead if I trade one share a day as if I trade 10 million." 42 This makes it difficult for smaller exchanges to compete. As an interviewee noted, 'Euronext is one example - an exchange without a strong market data or clearing business is always in a difficult situation strategically'; ${ }^{43}$ while another interviewee stated that 'mid-sized exchanges, such as Euronext, they are struggling to compete, to come up with their own USP in order to keep people from going to the bigger exchanges'. ${ }^{44}$ As a GEG's senior manager put it:

There are niche players that compete with us, but no one has the global coverage, no one works with as many market players. [...] Probably today [our infrastructure] is used by 110-120 external clients and then 30 of our own exchanges, and many banks and brokers - more than $100 \ldots$ So, that's a unique positioning. And it's hard to get into that space, because it is very costly, and our technology is IP-protected. ${ }^{45}$

And while smaller, innovative challengers are constantly emerging, GEGs will join the party if new business areas are lucrative. Take cryptocurrencies for example, CME runs 
the only regulated bitcoin futures market, ICE launched its own digital asset and payment platform (Bakkt) and several cryptocurrency exchanges are using Nasdaq technology (del Castillo 2019). When asked about blockchain challenging GEGs, Eurex Clearing's CEO replied: 'well, you still need someone to administer this blockchain'; ${ }^{46}$ and indeed, according to J.P. Morgan (2020), GEGs are leading the financial industry in adapting distributed-ledger-technology. Similarly, as ESG is beginning to shape the investment landscape, GEGs are buying ESG data companies, provide ESG-related services and list ESG-products (Muvija 2019). ${ }^{47}$

However, the power of GEGs is not unlimited. Neither do they control all infrastructures all the time, nor do they want to alienate their customers. Exchanges are profit-oriented enterprises and rely on clients using their services. ${ }^{48}$ As one interviewee noted: '[that's] the core of what exchanges do these days - we talk to clients and find out what the clients want, and then we use as much as we can of what the client tells us and go back and construct a product that is appropriate'. ${ }^{49}$ So, while their integrated business model puts them into an oligopolistic position and enables them to extract high rents, their power is limited as their customers might move their business to competitors (other GEGs) or try to partially substitute them (e.g. the establishment of MEMX, dark pools). They hence interact with the investor community to provide products and services at acceptable prices. ${ }^{50}$

Similarly, exchanges are also regulated and have to comply with the actions of states. In 2014, for instance, DBG's Clearstream had to pay a $\$ 152$ million fine for violating US sanctions after it 'provided the government of Iran with substantial and unauthorized access to the U.S. financial system' through a US-client's account (Yukhananov and Viswanatha 2014). However, in contrast to banks, ${ }^{51}$ trust in exchanges by investors and states has increased post-GFC (Botzem and Dahl 2014). According to several interviewees, exchanges largely benefitted from post-crisis regulations (EMIR, Dodd-Frank, IOSCO-PFMI, MiFID II), which they also influenced as lobby actors. ${ }^{52}$ As one interviewee noted, 'driven by post-GFC regulation, exchanges have certainly moved up in the value chain' ${ }^{53}$ and they have become more central as important actors 'at the intersections of finance'. ${ }^{54}$ Overall, while limited by competition and regulation, providing complementary infrastructural arrangements somewhat solidifies the structural power of GEGs.

\section{Conclusion: The Politics of Infrastructure Providers in the International Political Economy}

Exchanges are one of the institutional foundations of contemporary capitalism. However, they have so far not been understood as powerful actors in the politics of global finance. This paper argued that exchanges have changed fundamentally, having transformed from national marketplaces to global providers of financial market infrastructures. Today, exchanges are actors in their own right - global corporations whose business is to provide, govern and control large parts of global financial infrastructures: from market data and indices, to creating and facilitating the trading of various financial products, to post- 
trading activities such as central clearing. By providing infrastructures for capital markets, exchanges enable the functioning of these markets. But their new role as infrastructure providers also put exchanges in a position from which they can potentially exercise structural power over companies, investors and states entangled in these infrastructures, constraining and influencing their actions and 'changing the range of choices open to others without apparently putting pressure directly on them' (Strange 1988, p. 31); power that is concentrated within GEGs who dominate the majority of global capital market infrastructures. By looking at exchanges as global infrastructure providers, this paper highlights their importance as powerful actors in the politics of global finance.

While this paper provided an overview of exchanges, their transformation and how they have become powerful actors in global finance, this is by no means an exhaustive account of exchanges and their activities. Their power is of course not absolute or equally distributed, and more research is needed to analyse its specific manifestations and contestations. More detailed analyses of exchanges and their role within different aspects of financial infrastructures are required - from the private authority of index providers, the increasing relevance of CCPs, to power struggles about market data and access. Other aspects of exchanges' business models, e.g. payment system, central securities depositories or collateral management also merit further analysis, so does their integration into (self-)regulatory bodies and industry associations such as IOSCO, FIA or WFE. Challenges to the power of exchanges should also be further examined, for instance through developments in financial technology, other financial actors such as banks, dark pools or asset managers or how regulatory change might impact their central role in markets. Further, while this paper focused on GEGs, exchanges (and their transformations) are not uniform. China's state-owned exchanges most certainly occupy a different role in markets than GEGs in highly financialised US and European economies. A future avenue of research could therefore be a detailed, comparative analysis of exchanges in developed and emerging economies, their diverging roles in capital markets and how this translates into power vis-à-vis other actors.

As organisers of capital markets, exchanges should be concerned with the longterm stability of markets. However, most exchanges are now profit-driven businesses, while wielding substantial power over global markets. This is an important contradiction at the heart of exchanges because their roles as market organisers and market actors have conflicting incentives. As this power is concentrating within a few GEGs, this raises important questions about whether exchanges create new systemic vulnerabilities in the global financial system (Campbell-Verduyn et al. 2019) - for instance by creating HFT infrastructures that contributed to repeated flash crashes or by concentrating systemic risk within CCPs that might have incentives to lower margin requirements. While their own business models become more short term-oriented, what consequences does this have for the markets they organise? And are GEGs disseminating these potentially crisis-prone practices in e.g. developing countries' capital markets through technology transfers (author, 2020b)?

This is especially important considering the historically close relationship between states and exchanges. Until today, an image of exchanges as national icons with the quasi-public task of running (national) capital markets persists, and trust in exchanges 
remained relatively unquestioned post-crisis - exactly because they facilitate a neutral image of themselves (Botzem and Dahl 2014). But today exchanges are profit-oriented global corporations and as states become increasingly entangled with financial markets, their relationship has fundamentally changed as exchanges operate (many of) those infrastructures. In a changing post-crisis financial ecosystem and regulatory environment further research should analyse whether/how exchanges have become more integrated into hybrid systems of public-private governance. How has their relationship with states consequently changed?

On a more conceptual level, by highlighting the structural power of infrastructure providers the paper also contributes to current IPE debates on infrastructural power that often focuses on relational entanglements between states and (financial) markets. This does not only apply to global finance, but also to other infrastructure providers: from physical infrastructures like telecommunication, railway or logistics, the tech giants that facilitate platform capitalism, to the global competition for infrastructure provision initiated by China's Belt-and-Road-Initiative and the US-led Blue-Dot-Network. The structural power of infrastructure providers and the conditions for its emergence require further analysis.

Markets do not emerge out of a vacuum; they are created by actors such as exchanges. However, over the last decades exchanges have changed fundamentally and have become powerful actors in global finance. As crucial building blocks of global capitalism, their transformation requires further investigation. 


\section{Declaration of interest statement}

No potential conflict of interest was reported by the author.

\section{Funding}

This research was supported by the UK Economic and Social Research Council [grant number 1791638].

\section{Acknowledgements}

I would like to thank Adrienne Roberts, Arjan van der Heide, Chris May, Fabian Pape, Jan Fichtner, Lena Rethel, Ruben Kremers, Tim Sinclair, two anonymous reviewers as well as the participants of the Warwick Critical Finance Group Writeshop (3-4 September 2018) for their comments and feedback on previous versions of this paper.

\section{Notes}

1. One notable exception is MacKenzie (2018a, 2018b) who demonstrates how exchanges facilitate and shape HFT practices.

2. Interview: former CEO, global exchange (London, 8-Jan-2018).

3. The exchanges in this sample $(n=50)$ constitute the 20 largest stock exchanges and 20 largest derivatives exchanges globally in the years 2003 and 2018 (earlier ranking data is not consistent) measured by market capitalization (for stock exchanges) and trading volume (for futures exchanges); $\mathrm{n}=50$ due to $M \& A$ activities between entities.

4. Interview: business development department, global exchange (London, 11-Oct-2017).

5. These include the proposed SGX-ASX merger in 2011, NYSE Euronext and DBG in 2012, LSE-DBG in 2017 and LSE's attempted takeover of Canadian TMX in 2011.

6. Interview: CEO, asset manager (Singapore, 4-Dec-2017).

7. Interview: business development department, exchange (Frankfurt, 2-Nov-2017).

8. Interview: CEO, alternative trading system (London, 11-Oct-2017).

9. Interview: CEO, alternative trading system (London, 11-Oct-2017).

10. Interview: business development department, global exchange (London, 11-Oct-2017).

11. Analysed exchanges $(n=13)$ are: NYSE/Euronext/ICE, Nasdaq, B3, BME, JSE, JPX, LSE, DBG, TMX, SIX, SGX, HKEx, ASX; the sample analyses the top-20 stock exchanges by market capitalisation globally, excluding those whose financial reports are not detailed enough to comparatively analyse revenue developments (NSE, BSE, SSE, SZSE, TWSE, KRX; Euronext after demerger); revenues were normalised (baseline $=100$ for each exchanges' first year of reporting); not all exchanges started reporting in 1998. 
12. This transformation is probably more wide-reaching as reporting only started once stock exchanges became publicly listed, at which time transformation was already under way.

13. Interview: sales director, global exchange (London, 12-Oct-2017).

14. Interview: general manager, global exchange (Hong Kong, 5-Jul-2017).

15. Interview: former CEO, global exchange (London, 8-Jan-2018); importantly, as intransparent venues, dark pools cannot create marketable prices but rely on exchanges' data (interview: international department, global exchange; London, 10-Oct-2017).

16. Interview: data business director, global exchange (Singapore, 4-Dec-2017).

17. Interview: sales department, energy exchange (London, 17-Oct-2017); GEGs also acquired many data providers: Axioma (DBG), InteractiveData (ICE), Quandl (Nasdaq), LSE's pending acquisition of Refinitiv (aka Reuters).

18. In 2019, passive investment surpassed active investment in US stock markets (Gittelsohn 2019).

19. LSEG bought FTSE Russell in 2011, DBG fully acquired Stoxx in 2015, CME bought $90 \%$ of DJI, and S\&P DJI was established as a S\&P-CME joint venture.

20. Observation: Keynote speech, Eurex Derivatives Forum 2020 (Frankfurt, 28-Feb-2020).

21. Interview: regional office, global exchange (Beijing, 25-Oct-2018).

22. Interview: business development, index provider (Hong Kong, 27-Sep-2018).

23. Interview: Singapore (1-Dec-2017).

24. Interview: sales director, global exchange (London, 12-Oct-2017).

25. Interview: senior director, index provider (Hong Kong, 27-Sep-2018).

26. Interview: data business director, global exchange (Singapore, 4-Dec-2017).

27. As an interviewee noted: '[China's] CSI 300 was a reply to [SGX's] A50 Futures, the A50 pushed forward the Chinese government to make a quick decision' (research department, exchange; China, 18-Oct-2018).

28. Speech: Xi Jinping, 5th National Financial Work Conference (Beijing, 14-Jul-2017).

29. Interviewee: director, commodity trading platform (Hangzhou, 22-April-2018).

30. The figure for Europe is actually higher $(\sim 60 \%)$ as $48 \%$ of dark pool trading is conducted on exchange-owned dark pools (e.g. BATS, Turquoise, Acquis) but counted as off-exchange (Petrescu and Wedow 2017, pp. 4, 25).

31. Interview: international department, global exchange (London, 13-Oct-2017).

32. Interview: sales director, global exchange (London, 12-Oct-2017).

33. CCP interpose themselves between two counterparties in financial transactions, reducing counterparty credit and liquidity risk (Domanski et al. 2015, p. 2). Exchanges also ventured into other post-trade services, most notably settlement (ESCDA 2017, p. 11) which goes beyond the scope of this paper.

34. Interview: business development department, global exchange (London, 11-Oct-2017). 
35. Options Clearing Corporation is jointly owned by exchanges/members.

36. Interview: senior manager, financial infrastructure provider (London, 10-Jan-2018).

37. Interview: CEO, alternative trading system (London, 11-Oct-2017); also, interview: regional director, commodities exchange (Singapore, 8-Dec-2017).

38. Interview: Sales department, global exchange (Frankfurt, 24-April-2017).

39. For similar figures, see also: ICE

(https://s2.q4cdn.com/154085107/files/doc_presentations/ICE_Investor_Overview_2020 v2.pdf); CME (https://www.profit-loss.com/five-big-questions-following-the-cme-nexdeal-announcement/); SIX (https://www.sixgroup.com/dam/download/company/publications/SIX-all-cash-tender-offer-for-BMEpresentation-18-Nov-2019.pdf) (last accessed: 14-May-2020).

40. Interview: APAC director, global exchange (Hong Kong, 30-June-2017).

41. Interview: CEO, alternative trading system (London, 11-Oct-2017); also, interviews: business development, global exchange (Frankfurt, 2-Nov-2017); sales director, global exchange (London, 12-Oct-2017); sales department, energy exchange (London, 17-Oct2017).

42. Interview: CEO, alternative trading system (London, 11-Oct-2017).

43. Interview: international department, global exchange (London, 10-Oct-2017).

44. Interview: research department, exchange (London, 9-Oct-2017).

45. Interview: Hong Kong (5-Jul-2017).

46. Observation: Panel Discussion, Eurex Derivatives Forum 2020 (Frankfurt, 28-Feb-2020).

47. See also: https://www.deutsche-boerse.com/dbg-en/sustainability/build-trust/sustainableproducts-and-services, https://www.intercontinentalexchange.com/about/corporateresponsibility/sustainable-finance, https://www.nasdaq.com/solutions/esg-products (last accessed 15-May-2020).

48. Interview: former CEO, global exchange (London, 8-Jan-2018).

49. Interview: APAC director, global exchange (Hong Kong, 30-Jun-2017).

50. Interview: sales director, global exchange (London, 12-Oct-2017).

51. Interview: CEO, alternative trading system (London, 11-Oct-2017).

52. Interviews: financial industry association (Shanghai, 25-Apr-2018); CEO, alternative trading system (London, 11-Oct-2017); regional director, commodities exchange (Singapore, 8-Dec-2017); former CEO, global exchange (London, 8-Jan-2018); see also Pagliari (2018).

53. Interview: senior manager, financial infrastructure provider (London, 10-Jan-2018).

54. Interview: consultant, global exchange (London, 17-Oct-2017). 


\section{References}

Abolafia, M.Y., 1996. Making markets: Opportunism and restraint on Wall Street. Cambridge: Harvard University Press.

Aggarwal, R., 2002. Demutualization and corporate governance of stock exchanges. Journal of Applied Corporate Finance, 15 (1), 105-113.

Alloway, T., Burger, D. \& Evans, R., 2017. Index providers rule the world-for now, at least. Bloomberg, 27 November.

Baker, W.E., 1984. The social structure of a national securities market. American Journal of Sociology, 89 (4), 775-811.

Bernards, N. \& Campbell-Verduyn, M., 2019. Understanding technological change in global finance through infrastructures. Review of International Political Economy, 26 (5), 773-789.

Biglari, H., 2007. Strategic view: Exchanges seek a new model. Financial Times, 16 November.

Botzem, S. \& Dahl, M., 2014. Trust in transparency: Value dynamics and the reorganization of the Baltic financial markets. In: S. Alexius \& K.T. Hallström, eds. Configuring value conflicts in markets. Cheltenham: Edward Elgar, 63-81.

Bowker, G.C. \& Star, S.L., 1999. Sorting things out: Classification and its consequences. Cambridge: MIT Press.

Braudel, F., 1983. Civilization and capitalism, 15th-18th century: The wheels of commerce. New York: Harper \& Row.

Braun, B., 2016. From performativity to political economy: Index investing, ETFs and asset manager capitalism. New Political Economy, 21 (3), 257-273.

Braun, B., 2018. Central banking and the infrastructural power of finance: The case of ECB support for repo and securitization markets. Socio-Economic Review, 1-24.

Braun, B. \& Gabor, D., 2020. Central banking, shadow banking, and infrastructural power. In: P. Mader, D. Mertens \& N. Van der Zwan, eds. The Routledge international handbook of financialization. London: Routledge, 241-252.

Burton-Taylor, 2018a. Exchange global share \& segment sizing 2018. Osprey: BurtonTaylor International Consulting/TC-ICAP.

Burton-Taylor, 2018b. Index industry: Global share \& segment sizing 2018. Osprey: Burton-Taylor International Consulting/TC-ICAP.

Campbell-Verduyn, M., 2016. Merely TINCering around: The shifting private authority of technology, information and news corporations. Business and Politics, 18 (2), 143-170.

Campbell-Verduyn, M., Goguen, M. \& Porter, T., 2019. Finding fault lines in long chains of financial information. Review of International Political Economy, 26 (5), 911-937.

Castelle, M., et al., 2016. Where do electronic markets come from? Regulation and the transformation of financial exchanges. Economy \& Society, 45 (2), 166-200.

Cerny, P.G., 1989. The 'little big bang' in Paris: Financial market deregulation in a dirigiste system. European Journal of Political Research, 17 (2), 169-192.

Cohen, B.J., 1977. Organizing the world's money: The political economy of international monetary relations. London/Basingstoke: Macmillan Press.

Coombs, N., 2016. What is an algorithm? Financial regulation in the era of highfrequency trading. Economy and Society, 45 (2), 278-302.

Del Castillo, M., 2019. Nasdaq is now working with seven cryptocurrency exchanges. Forbes, 30 January. 
Domanski, D., Gambacorta, L. \& Picillo, C., 2015. Central clearing: Trends and current issues. BIS Quarterly Review, December, 59-76.

Domowitz, I., 1995. Electronic derivatives exchanges: Implicit mergers, network externalities, and standardization. The Quarterly Review of Economics and Finance, 35 (2), 163-175.

Edwards, P., 2003. Infrastructure and modernity: Force, time and social organization in the history of sociotechnical systems. In: T. Misa, P. Bray \& A. Feenberg, eds. Modernity and technology. Cambridge: MIT Press, 185-225.

Engelen, E. \& Grote, M.H., 2009. Stock exchange virtualisation and the decline of second-tier financial centres: The cases of Amsterdam and Frankfurt. Journal of Economic Geography, 9 (5), 679-696.

Ertürk, I., Leaver, A. \& Williams, K., 2010. Hedge funds as 'war machine': Making the positions work. New Political Economy, 15 (1), 9-28.

Ertürk, I. \& Solari, S., 2007. Banks as continuous reinvention. New Political Economy, 12 (3), 369-388.

ESCDA, 2017. European CSD factbook. Brussels: European Central Securities Depositories Association.

FIA, 2017. FIA global exchange volume dataset.

Brussels/Singapore/London/Washington: Futures Industry Association.

Fichtner, J., Heemskerk, E.M. \& Garcia-Bernardo, J., 2017. Hidden power of the big three? Passive index funds, re-concentration of corporate ownership, and new financial risk. Business \& Politics, 19 (2), 298-326.

FSB, et al., 2017. Analysis of central clearing interdependencies. CPMI Papers, 164, 5 July.

Gabor, D., 2016. The (impossible) repo trinity: The political economy of repo markets. Review of International Political Economy, 23 (6), 967-1000.

Gabor, D., 2020. Critical macro-finance: A theoretical lens. Finance \& Society, 6 (1).

Garratt, T. \& Hamilton, K., 2016. The loneliness of the long-term investor: A comment on patience in practice. Socio-Economic Review, 14 (4), 789-806.

Genito, L., 2019a. Mandatory clearing: The infrastructural authority of central counterparty clearing houses in the OTC derivatives market. Review of International Political Economy, 26 (5), 938-962.

Genito, L., 2019b. What markets fear: Understanding the European sovereign debt crisis through the lens of repo market liquidity. Thesis $(\mathrm{PhD})$. University of Warwick.

Gittelsohn, J., 2019. End of era: Passive equity funds surpass active in epic shift. Bloomberg, 11 September.

Gorham, M. \& Singh, N., 2009. Electronic exchanges: The global transformation from pits to bits. Burlington, MA: Elsevier.

Gravelle, M.J., 2016. The regulatory ties that bind markets: The political economy of cross-border integration in the exchange industry. Thesis $(\mathrm{PhD})$. University of British Columbia.

Hardie, I., 2012. Financialization and government borrowing capacity in emerging markets. Basingstoke: Palgrave Macmillan.

Helleiner, E., 1996. States and the reemergence of global finance: From Bretton Woods to the 1990s. Ithaca: Cornell University Press.

Helleiner, E., Pagliari, S. \& Spagna, I., eds., (2018) Governing the world's biggest market: The politics of derivatives regulation after the 2008 crisis. Oxford: Oxford University Press.

ICE, 2017. Annual report. Altanta: Intercontinental Exchange Group. 
ISDA, 2019. SwapsInfo third quarter of 2019 review. International Swaps and Derivatives Association, April.

J.P. Morgan, 2020. Blockchain, digital currency and cryptocurrency: Moving into the mainstream? J.P. Morgan Perspectives, Global Research, 21 February.

JPX, 2017. Annual report. Tokyo: Japan Exchange Group.

Khwaja, A., 2019. 2018 CCP market share statistics. ClarusFT Statistics, 29 January.

Knafo, S. \& Dutta, S.J., 2019. The myth of the shareholder revolution and the financialization of the firm. Review of International Political Economy, 1-24.

Krarup, T., 2019. Between competition and centralization: The new infrastructures of European finance. Economy \& Society, 48 (1), 107-126.

Lagna, A. \& Lenglet, M., 2019. The dark side of liquidity: Shedding light on dark pools' marketing and market-making. Consumption Markets \& Culture, 1-16.

Lagneau-Ymonet, P. \& Riva, A., 2012. Histoire de la bourse. Paris: La Découverte.

Lange, A.-C., Lenglet, M. \& Seyfert, R., 2016. Cultures of high-frequency trading: Mapping the landscape of algorithmic developments in contemporary financial markets. Economy \& Society, 45 (2), 149-165.

Lannoo, K. \& Valiante, D., 2010. The MiFID metamorphosis. European Capital Markets Institute, ECMI Policy Brief No. 16/October 2010.

Lavelle, K.C., 1999. International financial institutions and emerging capital markets in africa. Review of International Political Economy, 6 (2), 200-224.

Lee, R., 2002. The future of securities exchanges. The Wharton Financial Institutions Center, Working Paper, 02-14.

Lewis, M., 2014. Flash boys: A Wall Street revolt. New York: W.W. Norton \& Company.

Leyshon, A. \& Thrift, N., 2007. The capitalization of almost everything: The future of finance and capitalism. Theory, Culture \& Society, 24 (7-8), 97-115.

LSE, 2017. Annual report. London: London Stock Exchange Group.

Lütz, S., 1998. The revival of the nation-state? Stock exchange regulation in an era of globalized financial markets. Journal of European Public Policy, 5 (1), 153-168.

MacKenzie, D., 2006. An engine, not a camera. Cambridge, MA: MIT Press.

MacKenzie, D., 2018a. 'Making', 'taking' and the material political economy of algorithmic trading. Economy \& Society, 47 (4), 501-523.

MacKenzie, D., 2018b. Material signals: A historical sociology of high-frequency trading. American Journal of Sociology, 123 (6), 1635-1683.

MacKenzie, D., 2019. Market devices and structural dependency: The origins and development of 'dark pools'. Finance \& Society, 5 (1), 1-19.

MacKenzie, D., et al., 2012. Drilling through the Allegheny Mountains. Liquidity, materiality and high-frequency trading. Journal of Cultural Economy, 5 (3), 279-296.

Mann, M., 1984. The autonomous power of the state: Its origins, mechanisms and results. European Journal of Sociology, 25 (2), 185-213.

Mattli, W., 2019a. Darkness by design: The hidden power in global capital markets. Oxford: Oxford University Press.

Mattli, W., 2019b. Global algorithmic capital markets: High frequency trading, dark pools, and regulatory challenges. Oxford University Press.

Michie, R., 1999. The London stock exchange: A history. Oxford: Oxford University Press.

Millo, Y., 2007. Making things deliverable: The origins of index-based derivatives. The Sociological Review, 55 (2), 196-214. 
Moran, M., 1990. The politics of the financial services revolution the USA, UK and Japan. Basingstoke: Palgrave Macmillan.

Mügge, D., 2006. Private-public puzzles: Inter-firm competition and transnational private regulation. New Political Economy, 11 (2), 177-200.

Mügge, D., 2011. Widen the market, narrow the competition: Banker interests and the making of a European capital market. Colchester: ECPR Press.

Muniesa, F., 2011. Is a stock exchange a computer solution? Explicitness, algorithms and the Arizona Stock Exchange. International Journal of Actor-Network Theory and Technological Innovation, 3 (1), 1-15.

Muvija, M., 2019. London stock exchange buys data provider beyond ratings in esg push. Reuters, 3 June.

Nasdaq, 2017. Annual report (form 10-k). New York: Nasdaq Group.

Pagliari, S., 2018. The second half: Interest group conflicts and coalitions in the implementation of the Dodd-Frank Act derivatives rules. In: E. Helleiner, S. Pagliari \& I. Spagna, eds. Governing the world's biggest market: The politics of derivatives regulation after the 2008 crisis. Oxford: Oxford University Press, 137-167.

Pardo-Guerra, J.P., 2013. Making markets: Infrastructures, engineers and the moral technologies of finance. London School of Economics and Political Science.

Pardo-Guerra, J.P., 2019. Automating finance: Infrastructures, engineers, and relationmaking in electronic markets. Cambridge: Cambridge University Press.

Patterson, S., 2012. Dark pools: The rise of A.I. Trading machines and the looming threat to Wall Street. London: Random House Business Books.

Pauly, L., 1997. Who elected the bankers? Surveillance and control in the world economy. Ithaca: Cornell University Press.

Petrescu, M. \& Wedow, M., 2017. Dark pools in European equity markets: Emergence, competition and implications. ECB Occasional Paper Series, No 193 (July), 157.

Petry, J., 2020a. Financialization with Chinese characteristics? Exchanges, control and capital markets in authoritarian capitalism. Economy and Society, 49 (2), 213238.

Petry, J., 2020b. Securities exchanges: Subjects and agents of financialization. In: P. Mader, D. Mertens \& N. Van der Zwan, eds. The Routledge international handbook of financialization. London: Routledge, 253-264.

Petry, J., Fichtner, J. \& Heemskerk, E.M., 2019. Steering capital: The growing private authority of index providers in the age of passive asset management. Review of International Political Economy, 1-26.

Posner, E., 2009. The origins of Europe's new stock markets. Cambridge: Harvard University Press.

Quaglia, L., 2010. Completing the single market in financial services: The politics of competing advocacy coalitions. Journal of European Public Policy, 17 (7), 1007-1023.

Rauterberg, G.V. \& Verstein, A., 2013. Index theory: The law, promise and failure of financial indices. Yale Journal on Regulation, 30 (1), 101-162.

Reid, H. \& Jessop, S., 2017. Draining the dark pools? EU trading rules face uncertain launch. Reuters, 7 November.

Riles, A., 2011. Collatral knowledge: Legal reasoning in the global financial markets. Chicago: University of Chicago Press.

Robertson, B. \& Lam, E., 2019. UBS sees \$121 billion of em flows amid 'seismic' index shifts. Bloomberg, 11 February. 
Rooney, K., 2019. Wall street's trading powerhouses look to shake up US stock exchanges. $C N B C, 7$ January.

Scott, S.V. \& Barrett, M.I., 2005. Strategic risk positioning as sensemaking in crisis: The adoption of electronic trading at the London international financial futures and options exchange. The Journal of Strategic Information Systems, 14 (1), 45 68.

Seddon, J., 2019. Merchants against the bankers: The financialization of a commodity market. Review of International Political Economy, 1-31.

Sgambati, S., 2019. The art of leverage: A study of bank power, money-making and debt finance. Review of International Political Economy, 26 (2), 287-312.

SGX, 2018. Annual report. Singapore Exchange Group: Singapore.

SIFMA, 2019. Trends in capital markets. New York/Washington: SIFMA.

Sinclair, T.J., 2005. The new masters of capital: American bond rating agencies and the politics of creditworthiness. Ithaca: Cornell University Press.

SIX Group, 2020. Data is the fuel of financial markets. 8 May.

Skeete, H., 2008. A new breed of exchange. The Banker, 5 May.

Star, S.L., 1999. The ethnography of infrastructure. American Behavioral Scientist, 43 (3), 377-391.

Strange, S., 1986. Casino capitalism. Manchester: Manchester University Press.

Strange, S., 1987. The persistent myth of lost hegemony. International Organization, 41 (4), 551-574.

Strange, S., 1988. States and markets. London: Pinter.

The Economist, 2017. Financial-market index-makers are growing in power. The Economist, 24 August.

Thompson, G.F., 2017. Time, trading and algorithms in financial sector security. New Political Economy, 22 (1), 1-11.

Watson, M., 2005. Hedge funds, the Deutsche Börse affair and predatory angloAmerican capitalism. The Political Quarterly, 76 (4), 516-528.

Weitzman, H., 2011. Chicago's decade of innovation: 1972-1982. In: L. Harris, eds. Regulated exchanges: Dynamic agents of economic growth. Oxford: Oxford University Press, 174-201.

Wendt, F., 2015. Central counterparties: Addressing their too important to fail nature. IMF Working Paper, WP/15/21 (January), 1-24.

WFE, 2017. Statistics: Monthly report december 2017. London: World Federation of Exchanges.

Wójcik, D., 2012. The global stock market: Issuers, investors, and intermediaries in an uneven world. Oxford: Oxford University Press.

Yukhananov, A. \& Viswanatha, A., 2014. Deutsche Boerse to pay $\$ 152$ million in u.S. Sanctions probe. Reuters, 23 January.

Zaloom, C., 2006. Out of the pits: Traders and technology from Chicago to London. Chicago: University Chicago Press.

Zuboff, S., 2019. The age of surveillance capitalism: The fight for a human future at the new frontier of power. New York: PublicAffairs.

Zysman, J., 1983. Government, markets and growth: Financial systems and the politics of industrial change. Ithaca: Cornell University Press. 